\title{
Hemorrhoidal artery ligation without using a doppler guide: Is it a feasible and safe technique?
}

\author{
Mahmut Said Degerli, Dogan Yildirim, Mikail Cakir, Okan Murat Akturk, Orcun Alpay, \\ Alp Omer Canturk, Omer Faruk Kandas and Musaffer Akinci \\ Department of General Surgery, University of Health Seiences, Haseki Training and \\ Research Hospital, Istanbul, Turkey.
}

Key words: hemorrhoidal disease; hemorrhoidal artery ligation; doppler-guided hemorrhoidal artery ligation.

\begin{abstract}
The objective of this work was to analyze the results of the hemorrhoidal artery ligation technique without using a doppler guide, in patients with grade 3 hemorrhoidal disease; by evaluating cost-effectiveness, operation time, recurrence rate, postoperative pain, and secondary outcomes. A hemorrhoidal artery ligation procedure, without using a doppler guide, was performed on 43 patients ( 15 females, 28 males) with grade 3 symptomatic hemorrhoidal disease, from June 2015 to June 2019, in the Haseki Training and Research Hospital, Istanbul, Turkey. Patients were followed up clinically for one month. They completed a questionnaire within one year after their procedure. The median age was 46 years (range: 24 to 82 years). The main complaints were bleeding in 27 patients, pain in 22 patients, and skin tag in 14 patients. The mean preoperative VAS score was 3.4. The mean operating time was 18 mins (range: 13 to $25 \mathrm{~min}$ ). All patients remained hospitalized for $24 \mathrm{~h}$. Reoperation was necessary for only one patient because of bleeding. One year after the surgery, the pain was resolved in 21 (95.4\%) out of 22 patients with preoperative pain, and bleeding resolved in 25 (92.5\%) out of 27 patients with preoperative bleeding. The hemorrhoidal artery ligation is a simple method with a shorter learning curve producing similar postoperative results to other surgical procedures. The surgical technique is cost-effective as it does not require any particular device (anoscope with Doppler ultrasound) to apply.
\end{abstract}

Corresponding author: Mahmut Said Degerli. Department of General Surgery, University of Health Sciences, Haseki Training and Research Hospital, Istanbul, Turkey. Phone number: +90536957 86 88. E-mail: drmsdegerli@ gmail.com 


\title{
Ligadura de la arteria hemorroidal sin utilizar guia doppler: ¿Es una técnica factible y segura?
}

\author{
Invest Clin 2021; 62 (3): 230-235
}

Palabras clave: enfermedad hemorroidal; ligadura de la arteria hemorroidal; ligadura de la arteria hemorroidal guiada por doppler.

Resumen. El objetivo del trabajo fue analizar los resultados de la técnica de la ligadura hemorroidal sin usar una guía doppler en pacientes con enfermedad hemorroidal de grado 3, evaluando el costo-efectividad, el tiempo de operación, la tasa recurrente, el dolor posoperatorio y los resultados secundarios. Se realizó el procedimiento de la ligadura de la arteria hemorroidal, sin usar una guía doppler, en 43 pacientes (15 mujeres, 28 hombres) con enfermedad hemorroidal sintomática de grado 3, desde junio del 2015 hasta junio del 2019, en el "Haseki Training and Research Hospital, Istanbul, Turkey". Los pacientes tuvieron un seguimiento clínico por un mes. Ellos completaron un cuestionario dentro de un año después de su procedimiento. La edad media fue 46 años (rango, 24 a 82 años). Las principales quejas fueron sangrado en 27 pacientes, dolor en 22 pacientes y acrocordón de la piel en 14 pacientes. La puntuación media preoperatoria VAS fue 3.4. El tiempo medio de la operaciún fue 18 mins (rango: 13 a 25 min). Todos los pacientes quedaron hospitalizados por $24 \mathrm{~h}$. La re-operación fue necesaria para un solo paciente, debido al sangrado. Un año después de la cirugía, el dolor se resolvió en 21 de 22 pacientes $(95,4 \%)$ con dolor preoperatorio; y el sangrado se resolvió en 25 de 27 pacientes $(92,5 \%)$ con sangrado preoperatorio. La ligadura de la arteria hemorroidal es un método simple con una curva de aprendizaje más corta produciendo resultados postoperatorios similares a otros métodos. La técnica quirúrgica es rentable ya que no requiere utilizar ningún dispositivo en particular (anoscopio con ecografía doppler).

Received: 14-02-2021 Accepted: 15-05-2021

\section{INTRODUCTION}

Hemorrhoidal disease (HD) is one of the most frequent reasons for consultation in proctology. Between 4.4 and $39 \%$ of the general population is estimated to be affected by HD (1-3). There are three treatment options available in the literature to cure this disease: medical treatments, instrumental treatments (elastic ligation, sclerosis), and surgical treatments. Where conservative treatments have failed, surgical intervention needs to be performed to treat hemorrhoids.
There is no consensus on a gold standard treatment. Since excisional hemorrhoidectomy (EH) is associated with severe pain and a high rate of chronic complications, less invasive techniques have been developed with lower pain and complication rates. $\mathrm{EH}$ is still the preferred technique most widely used. Newer techniques, such as doppler-guided transanal hemorrhoidal artery ligation (DG $\mathrm{HAL}$ ), are considered alternatives to $\mathrm{EH}$ (Milligan-Morgan or Ferguson).

DG HAL was first described by Morinaga (4). DG HAL is a technique that uses an 
ultrasound probe to detect hemorrhoidal arteries for ligation. Studies that compare DG HAL and EH show that postoperative pain was lower and symptom resolution was significantly higher in the DG HAL procedure. No differences have been found in morbidity and recurrence rate $(5,6)$.

The purpose of the paper is to provide an overview of the hemorrhoidal artery ligation (HAL) technique. We analyze the results of the hemorrhoidal artery ligation technique without using a doppler guide in patients with grade 3 HD by evaluating costeffectiveness, operation time, recurrence rate, postoperative pain, and secondary outcomes.

\section{METHODOLOGY}

\section{Study design}

A retrospective observational study was conducted in patients with grade 3 hemorrhoidal disease treated with hemorrhoidal artery ligation without using a doppler guide (HAL) at our general surgery unit from June 2015 to June 2019. All patients were operated on by the same surgeon who has extensive experience in performing the procedure. The study was conducted with approval from the Ethics Committee of the University of Health Sciences, Haseki Training and Research Hospital (Ref No. 2020/79 Date: 27.05.2020).

Inclusion criteria: patients over 18 years old with grade 3 symptomatic hemorrhoidal disease who did not respond to conservative treatment.

Exclusion criteria were the following; previous anorectal surgery, HD other than grade 3, associated recto-anal disease (perianal fistulas, anal fissures, rectal prolapse, perianal abscess, fecal incontinence, anal stenosis).

Hemorrhoidal artery ligation without using a doppler guide was performed in 43 patients with grade 3 HD (15 females, 28 males). All patients were diagnosed with grade 3 hemorrhoidal disease via proctos- copy at our institution. The grade of HD was assessed based on Goligher's classification (7). Patients were followed up clinically for one month. They completed a questionnaire within one year after their procedure.

\section{Surgical Technique}

Preoperative preparation consisted of a cleaning enema administered the morning of surgery. No prophylactic antibiotics were administered. Operations were performed in the modified lithotomy position with legs spread apart on supports under spinal anesthesia.

The proctoscope was introduced into the anal canal. Distal branches of the superior rectal artery were conventionally positioned at 1, 3, 5, 7, 9, and $11 \mathrm{~h}$. After the exploration and identification of the hemorrhoids, hemorrhoidal packs were held with a clamp. Ligations were made with a $Z$-shape suture using 2-0 absorbable polyglycolic acid at $3 \mathrm{~cm}$ above the dentate line to the projection of the hemorrhoidal packs. No tissue was excised. No further procedures were performed.

\section{Postoperative care and complications}

All patients were hospitalized for $24 \mathrm{~h}$ after the procedure. The patients were discharged when adequate pain control and spontaneous micturition were achieved after examination by the surgeon to discard immediate complications. Postoperative consultations were scheduled to be held one week and one month after the procedure. The ambulatory treatment consisted of an osmotic laxative, and paracetamol ( $1 \mathrm{~g}$ ) for 7 days was preseribed to all the patients. No diet was suggested before or after the surgery.

During the scheduled appointments, none of the patients had anal stenosis or incontinence. Only one patient visited the hospital for bleeding. The patient was hospitalized for $48 \mathrm{~h}$ for blood transfusion, monitoring, blood pressure control, and re-operated (Milligan-Morgan). Complications were 
classified by Clavien-Dindo classification (8). No other complication or death had been recorded.

\section{Data Collection}

Pain was measured by using the Visual Analogic Scale (VAS), ranging from no pain (VAS:0) to the worst imaginable pain (VAS:10).

All patients were hospitalized for $24 \mathrm{~h}$ following the procedure. After the physical examination was performed and postoperative pain was recorded using the VAS, patients were discharged.

Documented postoperative symptoms, such as pain, bleeding, urinary retention, and rectal discomfort during scheduled appointments, were analyzed retrospectively.

\section{RESULTS}

The HAL procedure was performed on 43 patients with grade 3 symptomatic hemorrhoids (15 females and 28 males), from June 2015 to June 2019. The median age was 46 years (range: 24 to 82 years). All patients had a history of persistent hemorrhoidal symptoms despite receiving conservative treatments. All patients were diagnosed with grade 3 hemorrhoidal disease via proctoscopy in our institution. The main complaints were bleeding in 27 patients, pain in 22 patients, and skin tags in 14 patients. The mean preoperative VAS score was 3.4.

Spinal anesthesia was used for all patients. The mean operating time was $18 \mathrm{~min}$ (range: 13 and $25 \mathrm{~min}$ ). The number of hemorrhoidal artery ligations performed was two in six patients and three in 37 patients. All patients remained hospitalized for $24 \mathrm{~h}$.

When the complications were evaluated, reoperation in one patient because of bleeding was the only complication within 24 h. However, no significant complications were observed in any patient up to the 30 th postoperative day.
In the first postoperative week, tenesmus was reported by two patients, headache by seven, urinary retention was present in three, and superficial infection in one patient. However, all of these disappeared during the 13th-day controls.

In conclusion, one year after the surgery, the pain was resolved in 21 (95.4\%) of 22 patients with preoperative pain; bleeding resolved in $25(92.5 \%)$ out of 27 patients with preoperative bleeding. The mean VAS score was 1.1.

\section{DISCUSSION}

Hemorrhoidal disease is seen with a prevalence of up to even 39\% in the general population $(1,9)$. According to our clinical experience, the presence of such a high rate of hemorrhoidal disease is not an acceptable rate. Among the reasons for the high rates mentioned in the publications, we can count the patients' referring to every problem in the anus region as hemorrhoids, biases in survey studies, and problems in consulting a doctor about feelings of embarrassment. When reaching out to clinicians who can make the correct diagnosis, we believe that the $4.4 \%$ rate reported by Johanson et al. better reflects the reality (10).

While the widely accepted approach in its treatment is conservative, such as diet, lifestyle changes, and topical treatments in grade 1 and grade 2 diseases, more invasive treatments are necessary for grade 3 and grade 4 diseases (11-13).

The optimal procedure for the surgical treatment of hemorrhoidal disease is still controversial. New minimally invasive techniques have developed as an alternative to traditional and invasive procedures, such as excisional hemorrhoidectomy.

One of these techniques, DG-HAL, has become one of the leading surgical applications in treating symptomatic hemorrhoidal diseases (14). The technique has many advantages, such as being minimally invasive and easy to apply (15-17). 
In previous prospective randomized trials comparing DG HAL and EH, DG HAL produce less operative pain and morbidity with a similar long-term recurrence rate and report similar chronic complications after hemorrhoidectomy alone $(5,6)$. Carvajal-López et al. compared DG-HAL-RAR (doppler guided transanal hemorrhoidal artery ligation with recto-anal repair) with $\mathrm{EH}$ and found that the early postoperative pain was less in the group that underwent hemorrhoidal artery ligation (5). Trenti et al., in their study, compared DG-THD (doppler-guided transanal hemorrhoidal dearterialization with mucopexy) with conventional hemorrhoidectomy. These authors emphasized that DG-THD was not a more inferior technique than conventional surgery (18).

The disadvantages of the DG-HAL technique include requiring a special proctoscope with a doppler transducer, being costly; and the necessity for a learning process.

On the other hand, HAL is a simple method with a shorter learning curve that produces similar postoperative results. The surgical technique is cost-effective, as it does not require any particular device (doppler ultrasound anoscope) for its implementation. The HAL procedure offers shorter surgical time and similar postoperative outcomes using only sutures.

According to our HAL experience, the controls on the first and 13th days after surgery yielded follow-up results that were least dependent on the person and were least affected by subjective personal characteristics. In the first postoperative week, subjective complaints due to the surgical wound in the outpatient clinic were quite different from person to person, even increasing VAS score beyond levels of preoperative days. These complaints were temporary. Tenesmus was reported by two patients, headache by seven, urinary retention was present in three, and superficial infection in one patient. However, all of these disappeared during the 13th-day controls. Thus, more analytical results were obtained after one month. Therefore, the findings on the first and 30th days were emphasized more in the foreground in our study.

When we compare the results of our study with the literature, Hoyuela et al. found tenesmus was present in nine of their 30 patients $(30 \%)$, postoperatively, in their prospective study regarding DG-HAL-RAR. In our series, tenesmus was reported only by two patients $(4.65 \%)$. In the same study, the VAS score was 0.7 after one month (15). However, our VAS result was 1.1. In their DG-THD study, Trenti et al. found urinary retention in $9.6 \%$ of patients. In the study at hand, our rate of urinary retention was 6.9\% (18). Regarding headache, Bansal et al. reported $24 \%$ in their study, which was $16 \%$ in the present study (19). When superficial infections were evaluated, our results were similar compared to the literature; Trenti et al. reported a rate of $2.4 \%$, which was almost identical to our rate of $2.3 \%$ (18).

The design of this study has limitations. There were no DG HAL and EH groups to be compared. Further prospective studies that compare HAL and DG HAL techniques with a larger group of patients should be conducted.

\section{REFERENCES}

1. Loder PB, Kamm MA, Nicholls RJ, Phillips RK. Haemorrhoids: pathology, pathophysiology and aetiology. Br J Surg 1994; 81(7):946-954.

2. Mott T, Latimer K, Edwards C. Hemorrhoids: diaǵnosis and treatment options. Am Fam Physician 2018;97(3):172-179.

3. Hollingshead JR, Phillips RK. Haemorrhoids: modern diaǵnosis and treatment. Postgrad Med J 2016;92(1083):4-8.

4. Morinaga $K$, Hasuda $K$, Ikeda T. A novel therapy for internal hemorrhoids: ligation of the hemorrhoidal artery with a newly devised instrument (Moricorn) in conjunction with a Doppler flowmeter. Am J Gastroenterol 1995;90(4):610-613.

5. Carvajal López F, Hoyuela Alonso C, Juvany Gómez $M$, Troyano Escribano D, Trias Bisbal MA, Martrat Macià A, Ardid Brito J. Prospective randomized trial com- 
paring HAL-RAR versus excisional hemorrhoidectomy: postoperative pain, clinical outcomes, and quality of life. Surg Innov 2019;26(3):328-336.

6. Ferrandis C, De Faucal D, Fabreguette JM, Borie F. Efficacy of Doppler-guided hemorrhoidal artery ligation with mucopexy, in the short and long terms for patients with hemorrhoidal disease. Tech Coloproctol 2020;24(2):165-171.

7. Elmér SE, Nyǵren JO, Lenander CE. A randomized trial of transanal hemorrhoidal dearterialization with anopexy compared with open hemorrhoidectomy in the treatment of hemorrhoids. Dis Colon Rectum 2013;56(4):484-490.

8. Clavien PA, Barkun $J$, de Oliveira ML, Vauthey JN, Dindo D, Schulick RD, de Santibañes E, Pekolj J, Slankamenac K, Bassi C, Graf R, Vonlanthen R, Padbury R, Cameron JL, Makuuchi M. The Clavien-Dindo classification of surgical complications: five-year experience. Ann Surg 2009;250(2):187-196.

9. Riss S, Weiser FA, Schwameis K, Riss T, Mittlböck M, Steiner G, Stift A. The prevalence of hemorrhoids in adults. Int $\mathrm{J}$ Colorectal Dis 2012;27(2):215-220.

10. Johanson JF, Sonnenberg A. The prevalence of hemorrhoids and chronic constipation. An epidemiologic study. Gastroenterology 1990;98(2):380-386.

11. Alonso-Coello P, Guyatt G, Heels-Ansdell D, Johanson JF, Lopez-Yarto M, Mills E, Zhou Q. Laxatives for the treatment of hemorrhoids. Cochrane Database Syst Rev. 2005; (4):CD004649. Published 2005 Oet 19.

12. Alonso-Coello P, Zhou Q, Martinez-Zapata MJ, Mills E, Heels-Ansdell D, Johanson JF, Guyatt G. Meta-analysis of flavonoids for the treatment of haemorrhoids. Br J Surg 2006;93(8):909-920.

13. Perera N, Liolitsa D, Iype S, Croxford A, Yassin M, Lang P, Ukaegbu $O$, van Issum C. Phlebotonics for haemorrhoids. Cochrane Database Syst Rev 2012;(8):CD004322.
14. van Tol RR, Bruijnen MPA, Melenhorst $\mathbf{J}$, van Kuijk SMJ, Stassen LPS, Breukink SO. A national evaluation of the management practices of hemorrhoidal disease in the Netherlands. Int $\mathrm{J}$ Colorectal Dis 2018;33(5):577-588.

15. Hoyuela C, Carvajal F, Juvany M, Troyano D, Trias M, Martrat A, Ardid J, Obiols J. HAL-RAR (Doppler guided haemorrhoid artery ligation with recto-anal repair) is a safe and effective procedure for haemorrhoids. Results of a prospective study after twoyears follow-up. Int J Surg 2016;28:39-44.

16. Banai $Z$, Harkai $Z$, Király L, Szekeres P, Ottlecz I. HAL-RAR-mütét - egy új, noninvasiv lehetőség az aranyerek kezelésére [HAL-RAR for the treatment of hemorrhoids - a new, non invasive method]. Magy Seb 2019;72(4):161-166.

17. Rodoman GV, Kornev LV, Shalaeva TI, Malushenko RN. Éffektivnost> kombinirovannor̆ metodiki lecheniia gemorroia s ispol'zovaniem HAL-RAR i lazernoř destruktsii uzlov [Efficiency of combined methods of hemorroid treatment using hal-rar and laser destruction]. Khirurgiiia (Mosk). 2017;(5):47-51.

18. Trenti L, Biondo S, Galvez A, Bravo A, Cabrera J, Kreisler E. Correction to: Distal Doppler-guided transanal hemorrhoidal dearterialization with mucopexy versus conventional hemorrhoidectomy for grade III and IV hemorrhoids: postoperative morbidity and long-term outcomes. Tech Coloproctol 2018;22(6):479.

19. Bansal H, Jenaw RK, Mandia R, Yadav R. How to do open hemorrhoidectomy under local anesthesia and its comparison with spinal anesthesia. Indian J Surg 2012;74(4):330-333. 